\title{
Erratum to: Critical factors for the dimensional management system (DMS) implementation in manufacturing industries
}

\author{
Augusto Yassuo Teoi ${ }^{1} \cdot$ Rosley Anholon ${ }^{1}$ Dirceu da Silva ${ }^{1}$. \\ Osvaldo Luiz Gonçalves Quelhas ${ }^{2}$
}

Published online: 11 August 2016

(C) Springer-Verlag London 2016

Erratum to: Int J Adv Manuf Technol

DOI 10.1007/s00170-016-8824-9

The original version of this article unfortunately contained a mistake. The caption of Figs. 1 and 2 were exchanged. The correct captions are given below and the original article was corrected.

Fig. 1 Example of question

Fig. 2 Box plot format [63]

The online version of the original article can be found at http://dx.doi. org/10.1007/s00170-016-8824-9.

\footnotetext{
Rosley Anholon

rosley@ fem.unicamp.br

1 State University of Campinas, Campinas, Brazil

2 Fluminense Federal University, Niterói, Brazil
} 